\title{
Re-Conceptualising Public Health Interventions in Government: A Response to Recent Commentaries
}

\author{
Gemma Carey*
}

*Correspondence to: Gemma Carey, Email: G.Carey@adfa.edu.au Copyright: $\odot 2016$ by Kerman University of Medical Sciences Citation: Carey G. Re-Conceptualising public health interventions in government: a response to recent commentaries. Int J Health Policy Manag. 2016;5(9):569-570. doi:10.15171/ijhpm.2016.91

Received: 20 June 2016; Accepted: 2 July 2016; ePublished: 5 July 2016

$\mathrm{I}$ $\mathrm{n}$ their responses to 'Understanding the role of public administration in implementing action on the social determinants of health and health inequities,' ${ }^{\prime}$ authors Clavier, ${ }^{2}$ Breton, ${ }^{3}$ O'Flynn $^{4}$ and De Leeuw ${ }^{5}$ raise a range of additional insights from public administration and the frontline of public health policy advocacy. These include the importance of ideas and ideation processes, ${ }^{2}$ structural changes to policy administration and the creation of boundaries ${ }^{4}$ and the prominent but potentially limited initiative Health in All Policies (HiAP). ${ }^{3,4}$ When we put these together, an important confluence of ideas emerges that speak to contemporary public health challenges. In my response, I use HiAP as an anchor by which to interrogate how these insights might come together to focus our research and action agenda. HiAP is a prominent public health initiative aimed at changing the way that policy is 'done.6,7 As Breton' ${ }^{3}$ notes, however, its efficacy is yet to be established and work published elsewhere suggests that it may in fact be counterproductive to its very aims. ${ }^{8}$ Previously, colleagues and I have sought to bring conceptual clarity to this type of public health activity, which we view as a fundamentally different form of policy advocacy than public health has traditionally used. ${ }^{9}$ We argued that HiAP is an example of an instrumental process-based intervention' (IPI). 'Instrumental' because these interventions are not proposed as being inherently able to improve health but rather that their implementation will be instrumental in the creation of policy that improves health. Processbased, not simply in their focus upon government processes, but also because the interventions are usually constructed as introducing new decision-making or administration processes. And finally 'intervention' because initiatives like HiAP are designed to 'disturb the natural order' of policymaking by introducing new structures and processes. ${ }^{10}$ In public administration nomenclature, HiAP is a structural change to government - frequently suggested, commonly enacted, and notoriously unsuccessful in implementation. ${ }^{11}$ Properly (re)conceptualising HiAP and similar initiatives, rather than bundling them in with more traditional public health efforts (to enact a particular policy, such as tobacco laws), shifts the analytical focus of our research in an important way. Rather than tracking outcomes, it focuses our attention on the processes of government and the ways in which our interventions interact with and affect these in anticipated and unanticipated ways (from which outcomes emerge). It also encourages us to see that 'government' is a complex and contested context which needs to be properly investigated and understood, rather than treating it as a monolithic entity staffed by powerful elites. ${ }^{12}$

O'Flynn's ${ }^{4}$ piece highlights some of the important ways in which IPIs can interact with these contexts in ways that can be productive, un-productive, or neutral. Inherent in IPIs is a degree of formal restructuring, such as the creation of new teams and processes. ${ }^{9}$ As O'Flynn ${ }^{4}$ notes, restructuring creates what is known in public administration as 'boundary challenges.' When we restructure, we dissolve some boundaries but inevitably create new ones - not just structurally, but also symbolically and culturally., ${ }^{4,13}$ It is important to realise that attempts to 'disrupt the natural order' may not result in collaboration and unification as hoped, but can also generate coercive or even corrosive pressures., ${ }^{4,14}$ These often emerge from the relationships between formal institutions (the departments, groups, or processes) we put in place, and informal institutions (the actions and patterning of behaviour of individuals embedded in formal institutions). ${ }^{16}$ The interactions between the formal institutions that public health advocates for, and the informal institutional practices of actors, can be difficult to predict and can have serious unintended consequences. For example, Holt et $\mathrm{al}^{8}$ found that using HiAP drew policy-makers away from the major drivers of ill-health such as housing and poverty, to focus on smallerscale behaviour-based interventions. This result is counter to the very goals of HiAP. ${ }^{7,17,18}$

As Clavier notes, ideas and ideation processes are an important and often overlooked part of the policy and public administration process. Generally, the role of ideas and ideation processes in policy have been examined in terms of their relationship to specific policies. ${ }^{19,20}$ That is, 'ideas' are part of the construction of social, economic, and environmental problems that governments must address. However, ideas can also exert pressure on government to undertake other types of reform, such as altering the formal structures of institutions (eg, in an attempt to be better equip them to tackle emerging problems or in response to external pressures). The global spread of HiAP is one such example of how ideas can lead to the restructuring of government. The fact that this has occurred in the absence of engagement with the complex contexts of government, and the field which researches it, shows that interdisciplinary work between public administration and public health is not optional - it is 
an imperative.

\section{Acknowledgements}

Thanks to Ellie Malbon for reading an early draft and providing helpful feedback.

Ethical issues

Not applicable.

\section{Competing interests}

Author declares that she has no competing interests.

Author's contribution

$\mathrm{GC}$ is the single author of the paper.

\section{References}

1. Carey G. Understanding the role of public administration in implementing action on the social determinants of health and health inequities. Int J Health Policy Manag. 2015;4(12):795798. doi:10.15171/ijhpm.2015.185

2. Clavier C. Implementing health in all policies - time and ideas matter too! Comment on "Understanding the role of public administration in implementing action on the social determinants of health and health inequities." Int J Health Policy Manag. 2016; Forthcoming. doi:10.15171/ijhpm.2016.81

3. Breton E. A sophisticated architecture is indeed necessary for the implementation of health in all policies but not enough: Comment on "Understanding the Role of public administration in implementing action on the social determinants of health and health inequities." Int J Health Policy Manag. 2016;5(6):383-385. doi:10.15171/ijhpm.2016.28

4. O'Flynn J. From headline to hard grind: the importance of understanding public ad-ministration in achieving health outcomes: Comment on "Understanding the role of public administration in implementing action on the social determinants of health and health inequities." Int $\mathrm{J}$ Health Policy Manag. 2016;5(7):439-442. doi:10.15171/ijhpm.2016.49

5. de Leeuw E. We need action on social determinants of health - but do we want it, too? Comment on "Understanding the role of public administration in implementing action on the social determinants of health and health inequities." Int $J$ Health Policy Manag. 2016;5(6):379-382. doi:10.15171/ijhpm.2016.25

6. Freiler A, Muntaner C, Shankardass K, et al. Glossary for the implementation of health in all policies (HiAP). J Epidemiol
Community Health. 2013;67(12):1068-1072. doi:10.1136/jech2013-202731

7. Health in All Policies (HiAP). http://dhss.delaware.gov/dph/mh/ files/healthinallpoliciesguide.pdf. Accessed February 12, 2015. Published 2013.

8. Holt DH, Frohlich KL, Tjørnhøj-Thomsen T, Clavier C. Intersectoriality in Danish municipalities: corrupting the social determinants of health? Health Promot Int. 2016; Forthcoming. doi:10.1093/heapro/daw020

9. Carey G, Crammond B, Keast R. Creating change in government to address the social determinants of health: how can efforts be improved? BMC Public Health. 2014;14:1087. doi:10.1186/14712458-14-1087

10. Lynton J, McCrea J. The difference a day makes: Interim report for NHS Change Day. UK: National Health Service; 2013.

11. O'Flynn J. Crossing boundaries: The fundamental questions in public management. In: Blackman D, Halligan J, eds. Crossing Boundaries in Public Management and Policy: The International Experience. London: Routledge; 2014:11-44.

12. Pollitt $\mathrm{C}$. Context in public policy and management: the missing link? Edward Elgar Pub; 2013.

13. O'Flynn J. Some practical thoughts on working across boundaries. Occasional paper no. 14. Victoria, Australia: AZSOG; 2011. http://m.anzsog.edu.au/media/upload/publication/28 occpaper_14_oflynn.pdf. Accessed June 19, 2014.

14. Carey G, Crammond B, Riley T. Top-Down Approaches to JoinedUp Government: Examining the Unintended Consequences of Weak Implementation. Int J Public Adm. 2015;38(3):167-178. doi:10.1080/01900692.2014.903276

15. O'Flynn J, Buick F, Blackman D, Halligan J. You win some, you lose some: experiments with joined-up government. Int J Public Adm. 2011;34(4):244-254. doi:10.1080/01900692.2010.540703

16. Scott W. Unpacking institutional arguments. In: Powell W, DiMaggio P, eds. The New Institutionalism in Organisational Analysis. Chicago: University of Chicago Press; 1991:164-182.

17. Ollila E. Health in All Policies: From rhetoric to action. Scand $J$ Public Health. 2011;39(6 Suppl):11-18.

18. Sihto M, Ollilla E, Koivusalo M. Health in All Policies. In: Ståhl M, Wismar E, Ollilla E, Lahtinen E, Leppo K, eds. Health in All Policies: Prospects and Potentials. Finland: Ministry of Social Affairs and Health; 2006:3-21.

19. Béland D. Ideas, institutions, and policy change. J Eur Public Policy. 2009;16(5):701-718. doi:10.1080/13501760902983382

20. Béland D. Ideas and social policy: An institutionalist perspective. Soc Policy Adm. 2005;39(1):1-18. doi:10.1111/j.14679515.2005.00421.x 